\title{
Azadirachtin Biosynthesis Induction in Azadirachta indica A. Juss Cotyledonary Calli with Elicitor Agents
}

\author{
Marcelo Rodrigues ${ }^{1 *}$, Reginaldo Alves Festucci-Buselli ${ }^{2}$, Luzimar Campos Silva ${ }^{3}$ and \\ Wagner Campos Otoni ${ }^{3}$ \\ ${ }^{I}$ Departamento de Biologia; Setor de Fisiologia Vegetal; Universidade Federal de Lavras; Lavras - MG - Brasil. \\ ${ }^{2}$ Centro de Tecnologia Agropecuária; Instituto Sócio Ambiental e dos Recursos Hídricos; Universidade Federal \\ Rural da Amazônia; 66077-530; Belém - PA - Brasil. ${ }^{3}$ Departamento de Biologia Vegetal; Universidade Federal de \\ Viçosa; Viçosa - MG - Brasil
}

\begin{abstract}
The use of cell and plant tissues culture techniques to produce economically important active metabolites has been growing. Among these substances, azadirachtin (AZA), produced by the neem tree (Azadirachta indica), has received considerable attention due to its bioinsecticide action. The main goal of this work was to analyze the AZA levels in neem cotyledonary calli. The calli were grown in agitated Woody Plant Medium (WPM) liquid medium, supplemented with glucose (Gl), hydrolyzed casein (HC) and methyl jasmonate (MeJ) as elicitor agent. An interaction was observed between these substances, depending on in vitro cultivation time with orbital agitation. The highest concentrations (average of $0.2470 \mu \mathrm{g} \mathrm{g}^{-1}$ ) of AZA were produced in the first and second weeks of culture when the cell mass was grown in a medium with $2 \% \mathrm{Gl} v / \mathrm{v}, 500 \mathrm{mg} \mathrm{L}^{-1} \mathrm{HC}$ and $100 \mu \mathrm{M}$ of MeJ. This corresponded to approximately 57\% of the AZA content stored in the donor plants seeds, used as a source of explants to induce in vitro callus formation. It was concluded that the nutrition, as well as the concentration of MeJ as signal transduction of secondary metabolism in neem cells, might influence the AZA content produced in vitro.
\end{abstract}

Key words: Neem, HPLC, glucose, hydrolysed casein, methyl jasmonate

\section{INTRODUCTION}

The neem tree (Azadirachta indica A. Juss), syn Antela azadirachta, or Melia azadirachta L. belongs to the Meliaceae family (Cunha 2002). It is originated from Asia, native to Burma and arid regions of the Indian subcontinent, where there are approximately 18 million trees. It is currently grown in Australia, Africa and the Americas also. According to the US National Council of Investigation, neem has become one of the most promising plants worldwide for its various applications (Kundu 1999). It is used in human and veterinary medicine, in the cosmetics industry, as green manure, as a hardwood, and also for reforestation projects, or as an ornamental tree for landscaping.

The neem tree produces more than 300 secondary metabolites, a third of which are tetratriterpenoids (limonoids) with different biological effects and commercial applications (Dai et al. 2001; Neves et al. 2003; Rodrigues et al. 2012). The best known active compounds are azadirachtin (AZA), an insecticide and insect repellent, nimbin, a spermicide and anti-inflammatory in vertebrates, and salanim, another insect repellent. Of these, AZA (Fig. 1), which is stored mainly in the leaves and seeds Thengane et al. (1995), is the most economically important and abundant metabolite produced by $A$. indica (Mordue and Blackwell

*Author for correspondence: marcel.or.7@hotmail.com 
1993). AZA may cause changes in the insect development by repellent and intoxicating effects, affecting the physiology, oviposition and egg viability (Chopra 1958; Neves et al. 2003). Observations of the feeding behavior of some larvae (Spodoptera littoralis and Mamestra brassicae) indicated that AZA might also reduce the food consumption (Neves et al. 2003).

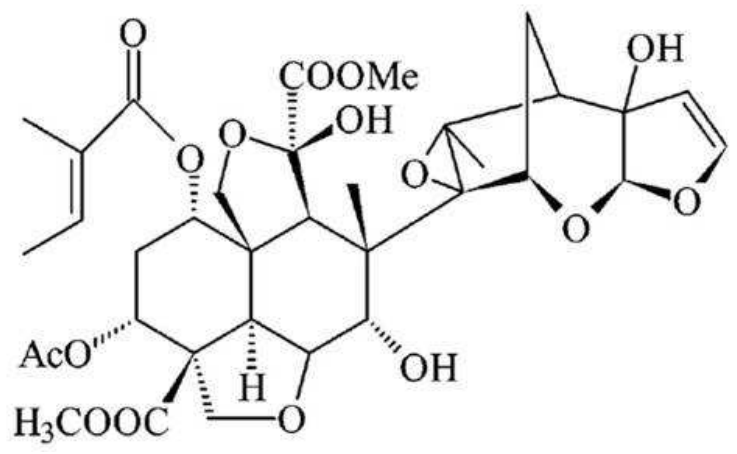

Figure 1 - The AZA molecule structure $\left(\mathrm{C}_{35} \mathrm{H}_{44} \mathrm{O}_{16}\right)$ is a tetratriterpenoid produced by Azadirachta indica, mainly stored in seeds and leaves.

AZA is a complex molecule that would be difficult to synthesize chemically. Thus, the cell and tissue culture approaches are the best options for in vitro production of these metabolites. The use of biotechnology may optimize the production of bioactive compounds through the use of elicitor agents and other methods (Prakash et al. 2002; Festucci-Buselli et al. 2008; Nakabayashi et al. 2010). However, AZA has not always been easy to detect using the standard techniques. For instance, Akula et al. (2003) was unable to detect the AZA in somatic embryos of neem using HPLC, even though the extract of somatic embryos was known to affect the development of locust larvae. This showed that somatic embryos synthesized the AZA, or another metabolite that affected the insect development. These apparent problems in HPLC analysis by UV detection may be caused by the low sensitivity of the detector, which lacks a strong-UV absorbing molecular chromophore. Such low sensitivity could cause errors in the quantification of AZA (Schaaf et al. 2000).

Secondary metabolites are produced by the plants mainly under stress conditions. The stresses may trigger the plant defense mechanisms, leading to a variety of biochemical signals, which induce the expression of genes related to secondary metabolite biosynthesis. The discovery of new compounds and their elicitors may allow the manipulation of their biosynthetic routes, increasing their yield in the tissue and cell cultures (Kim et al. 2009). To increase the yield, many scientists have used a technique based on the application of elicitors to a cultivation medium. This causes stress in the plant cells, signaling and activating defense mechanisms in the plants. Commonly used elicitors include carbohydrates, jasmonic acid (JA), methyl jasmonate (MeJ), salicylic acid (SA), chitosan and heavy metal ions (Nascimento and Fett Netto 2010).

The aim of this study was to assess in vitro production of AZA, using neem cotyledonary calli in agitated liquid medium cultures under the influence of different elicitor agents: glucose (Gl), hydrolysed casein (HC) and methyl jasmonate (MeJ).

\section{MATERIALS AND METHODS}

\section{Callus induction}

Neem plants (Azadirachta indica A. Juss) germinated in vitro were used as explant source. Seeds were collected at the Nim Brazil nursery garden in São José do Rio Preto, SP, Brazil. Cotyledons were inoculated on semisolid Woody Plant Medium - WPM Lloyd and McCown (1981) with $6 \mathrm{~g} \mathrm{~L}^{-1}$ granulated agar (Merck ${ }^{\circledR}$, Germany), and $3 \mathrm{mg} \mathrm{L}^{-1}$ 6-benzyladenine (BA) and $0.5 \mathrm{mg} \mathrm{L}^{-1}$ indolyl-3-butyric acid (IBA) (adapted methodology from Rodrigues et al. 2009), $\mathrm{pH}$ to 5.8. The medium was sterilized by autoclaving at $120^{\circ} \mathrm{C}$ during $15 \mathrm{~min}$ Aliquots $(10 \mathrm{~mL})$ were added to the test tubes $(25 \times 150 \mathrm{~mm})$ and closed with transparent polypropylene lids.

\section{Callus cultivation}

The calli were cultured in the flasks $(90 \mathrm{~mm}$ height, $50 \mathrm{~mm}$ diameter sealed with rigid poplyproplylene lids), containing $40 \mathrm{~mL}$ of semisolid WPM medium, added with $3 \mathrm{mg} \mathrm{L}^{-1} \mathrm{BA}$ and $0.5 \mathrm{mg} \mathrm{L}^{-1} \mathrm{IBA}$, and sub-cultured every 20 days. Six calli were transferred to each flask, with the same medium, growth regulators and concentrations, added with $200 \mathrm{mg} \mathrm{L}^{-1}$ myoinositol, $0.5 \mathrm{~g} \mathrm{~L}^{-1}$ polyvinyl pyrrolidone (PVP), $2 \%$ sucrose v/v, and B5 vitamins Gamborg et al. (1968) until the obtention of fresh mass calli for setting the experiment. The medium $\mathrm{pH}$ was adjusted to 5.8 previously to autoclaving at $120^{\circ} \mathrm{C}$ 
during $15 \mathrm{~min}$. The calli were cultivated in the dark. Three samples of cotyledonary calli were kept in $125 \mathrm{~mL}$ Erlenmeyer flasks with $40 \mathrm{~mL}$ of WPM liquid medium, with the same growth regulators and concentrations and placed on an orbital shaker at $90 \mathrm{rpm}$.

\section{Cultivation with inducing agents}

The agitated WPM liquid cultures were added with the following combinations of elicitors and evaluated for in vitro AZA production: 1- glucose (Gl) concentrations as carbon source $(0,1,2$, and $4 \% \mathrm{v} / \mathrm{v}) ; 2$ - hydrolyzed casein (HC) concentrations as nitrogen source $(0,250,500$, $\left.1000 \mathrm{mg} \mathrm{L}^{-1}\right) ; 3$ - methyl jasmonate (MeJ) concentrations as elicitor $(0,50,100,200 \mu \mathrm{M})$ versus time. Three treatments were used: $\mathrm{T} 0$ (control); $\mathrm{T} 1\left(1 \% \mathrm{Gl} \mathrm{v} / \mathrm{v}+250 \mathrm{mg} \mathrm{L}^{-1} \mathrm{HC}+50\right.$ $\mu \mathrm{M} \mathrm{MeJ}) ; \mathrm{T} 2\left(2 \% \mathrm{Gl} \mathrm{v} / \mathrm{v}+500 \mathrm{mg} \mathrm{L}^{-1} \mathrm{HC}+100\right.$ $\mu \mathrm{M} \mathrm{MeJ})$; and T3 (4\% Gl v/v + $1000 \mathrm{mg} \mathrm{L}^{-1} \mathrm{HC}+$ $200 \mu \mathrm{M}$ MeJ). Weekly periodic sampling (W1, W2, W3 and W4) was conducted. At the end of each week, three Erlenmeyers were sampled from each of the four treatments (12 Erlenmeyers in total). The dry mass was calculated after storage in an oven at $60^{\circ} \mathrm{C}$ for $24 \mathrm{~h}$, establishing a default value of $0.75 \mathrm{~g}$ per Erlenmeyer collected. The neem seeds were milled and dried to obtain the dry mass, mixed with methanol, filtered and injected into High Performance Liquid Chromatography (HPLC) in order to compare the AZA content produced in the treatments with natural levels.

\section{Methanol soluble extract obtainment}

Callus dry mass and seed dry mass were divided into three $0.25 \mathrm{~g}$ portions and stored in an Eppendorf with $1.0 \mathrm{~mL}$ of methanol per sample. After $24 \mathrm{~h}$, the samples were centrifuged at 3000 rpm for $10 \mathrm{~min}$, and subsequently injected into HPLC to determine the level of AZA present in the methanol soluble extract.

\section{AZA content determination}

AZA content analysis was performed using the HPLC (Shimadzu SPD-M10AVP Diode Array Detector) equipment, following the method described by Schaaf et al. (2000), with some modifications. Ultraviolet (UV) was used as detector with a $217 \mathrm{~nm}$ wavelength. A Bondesil C18 reverse phase column $(5 \mu \mathrm{m} \times 4.6 \mathrm{~mm} \times 250$ $\mathrm{mm}$ ) was used, with $1.0 \mathrm{~mL} \mathrm{~min}^{-1}$ flow and column pressure at $97 \mathrm{Kgf}$. The mobile phase solvent was methanol and water $(50: 50 \mathrm{v} / \mathrm{v})$, and the injected volume for each run was $50 \mu \mathrm{L}$. The run time was $30 \mathrm{~min}$. The mobile phase was filtered with $0.45 \mu \mathrm{m}$ Millipore membrane and degassed with helium. The data were integrated by the Shimadzu SPD software. To set the calibration curve, AZA with $95 \%$ purity (Sigma Aldrich, EUA) was used at concentrations of 0 ; 0.0125 ; $0.025 ; 0.05 ; 0.1 ; 0.2$ and $0.4 \mu \mathrm{g} \mathrm{L}^{-1}$ in methanol. The resulting chromatogram values were plotted and a linear equation (Fig. 2) was used to calculate the AZA content of the samples. The natural extract of neem seeds was analyzed under the identical conditions.

\section{Experimental design}

A simple factorial design $(3 \times 4)$ was used, comparing the concentrations of AZA and the elicitor agents over different collection weeks, with nine replicates per treatment. The data were submitted to the variance analysis of the GENES software, version Windows/2004.2.1 to Cruz (2002), using the Tukey post-hoc test with two factors and a 5\% significance level.

\section{RESULTS AND DISCUSSION}

Azadirachtin is a tetraterpenoid and is the most abundant molecule in neem seeds when compared to other limonoids. The detected AZA content of the seed extract was higher than the cultivated calli when analyzed with a UV wavelength of $217 \mathrm{~nm}$. Such contrasts could occur when there was a differential in vitro gene expression of several neem secondary metabolites. Differences in the gene expression are caused by the somaclonal variation in the explants during the sub-cultures (Kota et al. 2006; Lima et al. 2008). On the other hand, this somaclonal variation can be a useful source of new variation for genetic breeding, mainly for the selection of cell lines with higher yield (Carvalho et al. 2013). The a appearance of the calli (Fig. 2A) cultivated in the semisolid medium prior to liquid medium as well as the AZA calibration curve is shown in Figure 2B. A two-phase system was used for the induction of the rapid cell growth. Growth regulators were used and then the cells were exposed to a liquid medium containing elicitor agents: $\mathrm{Gl}$ as carbon source, $\mathrm{HC}$ as nitrogen source and $\mathrm{MeJ}$ as signal transduction of secondary metabolism in neem cells in vitro. 


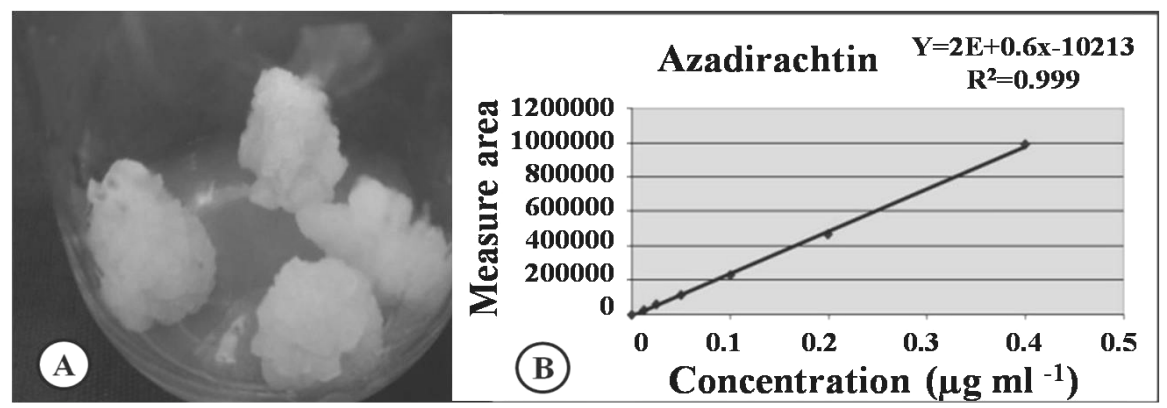

Figure 2 - Azadirachta indica cotyledonary calli subcultured every 30 days in Woody Plant Medium WPM. A) Calli from the ninth subculture in semisolid medium, then transferred to liquid medium; B) Linear regression of the AZA calibration, with $\mathrm{R}^{2}=0.999$.

The AZA production process can be optimized, when two phases are taken. The first phase is characterized by high nitrogen and phosphorus contents to increase the biomass. The second phase uses low concentrations of minerals, inducing the nutritional stress in the explants and reducing the oxygen transference rate (OTR). Consequently, there may be increase in the AZA production. According Raval et al. (2003), the highest AZA concentration $\left(0.8 \mathrm{mg} \mathrm{L}^{-1}\right.$ extract) was related with the cells at the ninth day of cultivation in White's Medium (White 1963). However, after applying this two-phase system, the highest AZA concentration produced in vitro reached $67.5 \%\left(2.7 \mathrm{mg} / \mathrm{L}^{-1}\right.$ extract $)$ in callus cultures from the shoots, using the modified Murashige and Skoog (MS) medium with different concentrations of nitrogen and phosphorus sources in suspension culture callus, relative to the average content of the compound in natural seeds (Raval et al. 2003). These results indicated that the biomass growth was not directly related to the in vitro production of AZA, but directly related to the decrease of the OTR associated with the stationary phase of cell growth. The nutrient type and its concentration are primordial to the cell expansion and development.

Based on the chromatogram (Fig. 3), the standard AZA retention time was $13.617 \mathrm{~min}$, with higherer production of AZA in second week, when the cell was cultivated in WPM liquid medium with $2 \% \mathrm{Gl} \mathrm{v} / \mathrm{v}+$ $500 \mathrm{mg} \mathrm{L}^{-1} \mathrm{HC}$ and $100 \mu \mathrm{M}$ of $\mathrm{MeJ}$ (T2W2) took $13.525 \mathrm{~min}$. By superposition, the analyzed compound was considered AZA due to the similarity of the retention time of the standard and sample.

There was significant interaction between the elicitor agent concentrations as a function of sample collection time. The highest AZA concentration was produced by the T2 treatment with $2 \% \mathrm{Gl} \mathrm{v/v,} 500 \mathrm{mg} \mathrm{L}^{-1} \mathrm{HC}$ and $100 \mu \mathrm{M}$ MeJ (Fig. 4).

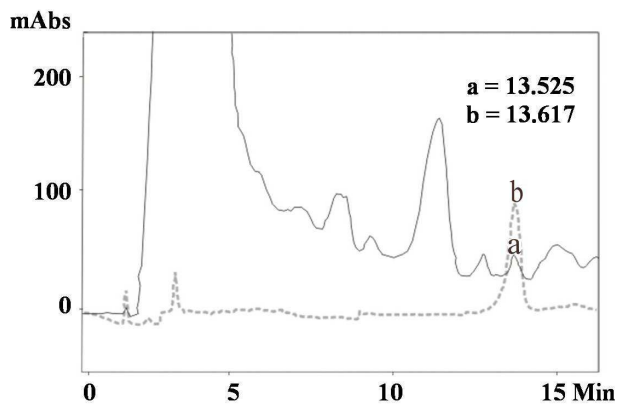

Figure 3 - HPLC chromatogram. Retention time of the standard $-95 \%$ purity AZA (Sigma Aldrich, USA): $\mathrm{b}=13.617 \mathrm{~min}$, dotted line; treatment 2 and week $2\left(\mathrm{~T} 2 \mathrm{~W} 2=2 \% \mathrm{Gl} \mathrm{v} / \mathrm{v}+500 \mathrm{mg} \mathrm{L}^{-1}\right.$ $\mathrm{HC}+100 \mu \mathrm{M} \mathrm{MeJ}): \mathrm{a}=13.525 \mathrm{~min}$ in solid line.

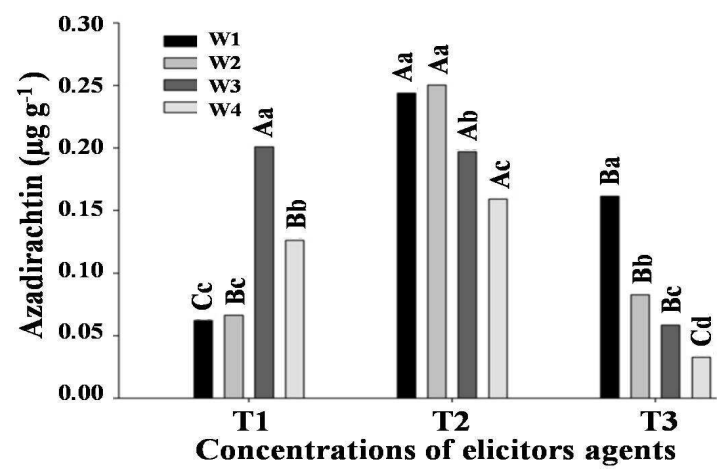

Figure 4 - AZA concentration ( $\mu \mathrm{g}$ per gram of callus dry mass) as affected by elicitor agents: T1 [1\% glucose (Gl) $\mathrm{v} / \mathrm{v}+250 \mathrm{mg} \mathrm{L}^{-1}$ hydrolized casein $(\mathrm{HC})+50 \mu \mathrm{m}$ methyl jasmonate $(\mathrm{MeJ})]$; $\mathrm{T} 2\left[2 \%(\mathrm{Gl}) \mathrm{v} / \mathrm{v}+500 \mathrm{mg} \mathrm{L}^{-1}(\mathrm{HC})+\right.$ $100 \mu \mathrm{M}(\mathrm{MeJ})]$ and T3 [4\% (Gl) v/v + $1000 \mathrm{mg} \mathrm{L}^{-1}(\mathrm{HC})+$ $200 \mu \mathrm{M}(\mathrm{MeJ})]$, as a function of the weekly collection (W1 to W4).

The lowercase letters indicate differences among weeks in a same concentration of elicitors agents and the uppercase letters indicate differences for a week among concentrations, at $5 \%$ by the Tukey's test. 
The first and second weeks had the highest production rates with an average AZA concentration of $0.247 \mu \mathrm{g}$ per gram of callus dry mass in the fifth subculture at 15 days intervals. The control samples (without elicitor agents) resulted AZA only in traces, and therefore, no area integration was performed (in chromatograms). Apparently increased production of bioactive compounds with use of elicitor agents, may relate to the "Rate Growth Hypothesis" Stamp (2003), which suggests that when the maximum growth decreases, the rates from the constitutive defense levels increase. The lower amount of carbon and nutrients assimilated by the cell - related to the increase in osmotic potential - cause an increase in secondary metabolites production. The AZA content of the treatment T2W2 $(2 \% \mathrm{Gl} v / \mathrm{v}+500$ $\left.\mathrm{mg} / \mathrm{L}^{-1} \mathrm{HC}+100 \mu \mathrm{M} \mathrm{MeJ}\right)$ corresponded to $57 \%$ of the AZA stored in the seeds derived from the adult neem plants $\left(0.4301 \mu \mathrm{g} \mathrm{g}^{-1}\right)$.

Abiotic stresses can affect the chemical composition and amount of essential oils produced by the plants. The biochemical and chemical agents may favor the biochemical signaling of the different metabolic pathways the production of bioactive compounds (Guillon et al. 2006). The perception of the elicitor signal leads to the activation of transduction factors that regulate the expression of the genes involved in the biosynthesis of secondary metabolites. These substances can also modify the conformation, or activation of kinase receptors by activating their effectors, such as ion channels, protein $G$, and lipases, which are responsible for translating the elicitor signal into the plant's defense response. The locations of the ligation of elicitor signals have been identified in the plasma membrane of various plant species. These signals can be biochemical or chemical, and are able to effectively influence the synthesis of secondary metabolites in vitro (Zhao et al. 2005).

Glucose is a better carbon source than sucrose for biomass production and is capable of stimulating higher production of the AZA, because glucose is a monosaccharide that has better access to the cells, being a primary energy source to the cells. Apparently, sucrose, after being taken up from the culture media, was hydrolyzed to glucose and fructose by the cell wall bound invertases (Martinez and Park 1993). The slow consumption of sucrose might be due to low activity of the invertase. The selection of carbon source (glucose, or sucrose) has long been recognized as an important factor in the production of secondary metabolites by the plant cell cultures (Chattopadhyay et al. 2002).

Nitrate nitrogen is a better nitrogen source than ammonia for biomass production and for stimulating AZA accumulation in vitro. The maximum biomass was $15.02 \mathrm{~g} \mathrm{~L}^{-1}$ calli and 2.98 $\mathrm{mg} / \mathrm{g}^{-1}$ of AZA per gram of callus, 12 days after the cultivation of the suspension culture. Seed kernel (along with embryo) was, thereafter, excised and used as an explant for callus induction on MS medium, optimizing the nutritional composition of the culture medium and additives. Indeed, the high ammonium concentration inhibited the cell growth and AZA production (Prakash and Srivastava 2005). According to Sujanya et al. (2008), $94.41 \mathrm{~mm}$ of nitrate, 23.60 $\mathrm{mm}(4: 1)$ of ammonium and a reduction in sucrose content $\left(15 \mathrm{mg} \mathrm{L}^{-1}\right)$ increased the AZA production (5.59 $\mathrm{mg} \mathrm{L}^{-1}$ ) in MS medium with $1.0 \mathrm{mg} \mathrm{L}^{-1} \mathrm{NAA}$ and $3.0 \mathrm{mg} \mathrm{L}^{-1}$ BA. However, a biomass reduction (7.4\%) was also recorded when the cell suspensions were established from the nodal segments. Some solutes of low molecular weight such as ammonium, aminoacids (proline) and poliols (sorbitol and mannitol), sugars (sucrose, glucose, fructose and threalose), are considered osmoprotectors because they are highly soluble and directly influence the synthesis and accumulation of secondary metabolites in plants (Berenguer et al. 2008; Suriyan et al. 2009).

Nutrition is known to directly influence the content of AZA, mainly through its impact on carbon sources (Prakash et al. 2002). MeJ and JA, in their role as signal transduction elements in the pathways of secondary metabolites, have been used to induce the production of economically important compounds. MeJ has some limitations for long term induction of secondary metabolites in certain crops. For example, the cells of Silybum marianum elicited with $\mathrm{MeJ}$ for the production of silimarin showed a gradual decrease in the level of this compound throughout the successive subcultures (Sanchez-Sampedro et al. 2009). Ohyama and Nitsch's (1972) culture medium produced the highest in vitro yield of AZA $(0.0166 \%$ dry mass). Adding elicitor agents such as JA $(100 \mathrm{~mm})$ and SA at $100 \mathrm{~mm}$, resulted in 6folds $(0.095 \%)$ and 9-folds $(0.14 \%)$ increase, respectively in the production of AZA in neem root explants (Satdive et al. 2007). Biotic and abiotic elicitor agents have been recommended as an important strategy to optimize the in vitro 
generation of secondary metabolites (Savitha et al. 2006).

$\mathrm{JA}$ is a signaling agent for the production of bioactive compounds in the plants, which undergo mechanical stress by the insects (Prakash and Srivastava 2008). Thus, AZA production and content observed in this work were probably influenced by the nutrition system in the culture medium and the concentration of agents used to stimulate its biosynthesis. Elicitors agents such as chitosan, SA, JA, MeJ and yeast extract have been used in neem cell suspension to promote higher levels of the AZA in vitro production. The combination of these agents could enable up to 5folds increase in AZA production $\left(15.9 \mathrm{mg} \mathrm{L}^{-1}\right)$ due to synergism after two days of cultivation. Using NAA and elicitor agents in a bioreactor, the AZA concentration reached $161.1 \mathrm{mg} \mathrm{L}^{-1}$. The addition of lower concentrations of SA $\left(14 \mathrm{mg} \mathrm{L}^{-1}\right)$ resulted in an inhibitory effect, but high concentrations $\left(70 \mathrm{mg} \mathrm{L}^{-1}\right)$ resulted in an increase in AZA (16.8 $\mathrm{g} \mathrm{L}^{-1}$ ) (Prakash and Srivastava 2008). Another stimulator of AZA production was high concentrations of yeast extract $\left(100 \mathrm{mg} \mathrm{L}^{-1}\right)$, which resulted in $6.5 \mathrm{mg} \mathrm{g}^{-1}$ of production. The most promising combinations of elicitors used in neem cell suspension were SA plus JA, and chitosan plus SA at the following concentrations: $\mathrm{SA}=137.3 \mathrm{mg} \mathrm{L}^{-1} ; \mathrm{JA}=2.9 \mathrm{mg} \mathrm{L}^{-1}$ and chitosan $=$ $16.5 \mathrm{mg} \mathrm{L}^{-1}$. Under these conditions, AZA content reached $18.4 \mathrm{mg} \mathrm{g}^{-1}$ due to molecule synergism after 10 days of cultivation. However, later there was a reduction in concentration (Prakash and Srivastava 2008). Similar results were obtained in the present work. Overall, in vitro yield was still low indicating that more studies to optimize the production of AZA were required. The relationship between the cell growth/multiplication and in vitro AZA production was not elucidated. This relationship was non-linear, indicating a complex and possibly indirect relationship between these processes. It has been reported that more than $70 \%$ of AZA biological activity can be lost after 30 days of storage (Allan et al. 2002).

\section{CONCLUSIONS}

High azadirachtin concentrations were obtained in the first and second weeks of cultivation. The highest average value was $0.2470 \mu \mathrm{g} \mathrm{g}^{-1}$ in the second week, when the cell mass was cultivated in an orbital agitated WPM liquid medium supplemented with $3.0 \mathrm{mg} \mathrm{L}^{-1} \mathrm{BA}, 0.5 \mathrm{mg} \mathrm{L}^{-1}$ IBA, $2 \% \mathrm{Gl} \mathrm{v} / \mathrm{v}+500 \mathrm{mg} \mathrm{L}^{-1} \mathrm{HC}$, and $100 \mu \mathrm{M}$ MeJ.

\section{ACKNOWLEDGEMENTS}

The authors thank Dr. Everaldo Gonçalves de Barros for making available laboratory facilities for HPLC analyses, and to Eduardo Rezende Pereira for his technical assistance. MR was recipient of a scholarship from $\mathrm{CNPq}$.

\section{REFERENCES}

Akula C, Akula A, Drew R. Somatic embryogenesis in clonal neem, Azdirachta indica. A. Juss. and analysis for in vitro azadirachtin production. In Vitro Cell Dev Biol Plant. 2003; 39(3): 304-310.

Allan EJ, Eeswara JP, Jarvis AP, Mordue AJ, Morgan ED, Stuchbury T. Induction of hairy root cultures of Azadirachta indica A. Juss. and their production of azadirachtin and other important insect bioactive metabolites. Plant Cell Rep. 2002; 21(4): 374-379.

Berenguer LC, Ballesta MCM, Viguera GC, Carvajal M. Leaf water balance mediated by aquaporins under salt stress and associated glucosinolate synthesis in broccoli. Plant Sci. 2008; 174(3): 321-328.

Carvalho DC, Silva ALL, Schuck MR, Purcino M, Tanno GN, Biasi LA. Fox grape cv. Bordô (Vitis labrusca L.) and grapevine cv. Chardonnay (Vitis vinifera L.) cultivated in vitro under different carbohydrates, amino acids and 6-benzylaminopurine levels. Braz Arch Biol Technol. 2013; 56(2): 191-201.

Chattopadhyay S, Srivastava Ak, Bhojwani SS, Bisaria VS. Production of podophyllotoxin by plant cell cultures of Podophyllum hexandrum in bioreactor. $J$ Biosc Bioeng. 2002; 93(2): 215-220.

Chopra RN. The neem (Melia azadirachta L. Meliaceae). In: Chopra RN, editor. Indigenous drugs of India. $2^{\text {nd }}$ ed. Nova Delhi: Academic Publishers, 1958. p. 360-363.

Cruz CD. Programa Genes, release versão Windows. 2002. Editora UFV, Viçosa.

Cunha RAS. Nim indiano: a árvore milagrosa. Vetores e Pragas. 2002; 4: 1-5.

Dai J, Yaylayan V, Vijaya A, Raghvan GS, Pare JR, Liu Z. Multivariate calibration for the determination of total AZRL and simple terpenoids in neem extracts using vanillin assay. J Agr Food Chem. 2001; 49(3): 1169-1174. 
Festucci-Buselli RA, Contim LAS, Barbosa LCA, Stuart JJ, Otoni WC. Biosynthesis and potential functions of the ecdysteroid 20-hydroxyecdysone - a review. Botany. 2008; 86(9): 978-987.

Gamborg OL, Miller RA, Ojima K. Nutrient requirements of suspension cultures of soybean root cells. Exp Cell Res. 1968; 50(1): 150-158.

Guillon S, Trémouillaux-Guiller J, Pati PK, Rideau M, Gantet P. Hairy root research: recent scenario and exciting prospects. Curr Opin Plant Biol. 2006; 9(3): 341-346.

Kim HJ, Ono E, Morimoto K, Yamagaki T, Okazawa A, Kobayashi A, Satake H. Metabolic engineering of lignan biosynthesis in Forsythia sp. cell culture. Plant Cell Physiol. 2009; 50(12): 2200-2209.

Kota S, Raghupati-Rao ND, Chary P. In vitro response of select regions of Azadirachta indica A. Juss (Meliaceae) as elucidated by biochemical and molecular variations. Curr Sci India. 2006; 91(6): 770-776.

Kundu SK. The mating system and genetic significance of polycarpy in the neem tree (Azadirachta indica). Theor Appl Genet 1999; 99(7-8): 1216-1220.

Lima EC, Paiva R, Nogueira RC, Soares FP, Emrich EB, Silva AAN. Callus induction in leaf segments of Croton urucurana Baill. Ciênc Agrotec. 2008; 32(1): 17-22.

Lloyd G, McCown B. Commercially-feasible micropropagation of Mountain laurel, Kalmia latifolia, by use of shoot tip culture. Proc Intl Plant Prop Soc. 1981; 30: 421-427.

Martinez BC, Park CH. Characteristics of batch suspension cultures of preconditioned Coleus blumei cells: sucrose effect. Biotechnol Prog. 1993; 9: 97100.

Mordue AJ, Blackwell A. Azadirachtin: an update. $J$ Insect Physiol. 1993; 39(11): 903-924.

Nakabayashi R, Yamazaki M, Saito K. A polyhedral approach for understanding flavonoid biosynthesis in Arabidopsis. New Biotech. 2010; 27(6): 829-836.

Nascimento NC, Fett-Neto AG. Plant secondary metabolism and challenges in modifying its operation an overview. In: Fett-Neto AG, editor. Plant secondary metabolism engineering, Methods in Molecular Biology. Dordrecht: Humana Press; 2010. p. 1-13.

Neves BP, Oliveira IP, Nogueira JCM. Cultivo e utilização do nim indiano (Azadirachta indica A. Juss.). Goiânia: EMBRAPA-CNPAF-APA (Circular Técnica). 2003; 62: 1-31.

Ohyama K, Nitsch JP. Flowering haploid plants obtained from protoplasts of tobacco leaves. Plant Cell Physiol. 1972; 13(2): 229-236.
Prakash G, Bhojwani S, Srivastava AK. Production of azadirachtin from plant tissue culture: state of the art and future prospects. Biotechnol Biopr Eng. 2002; 7(4): 185-193.

Prakash G, Srivastava AK. Statistical media optimization for cell growth and azadirachtin production in Azadirachta indica (A. Juss) suspension cultures. Process Biochem. 2005; 40(12): 3795-3800.

Prakash G, Srivastava AK. Statistical elicitor optimization studies for the enhancement of azadirachtin production in bioreactor Azadirachta indica cell cultivation. Biochem Eng J. 2008; 40(2): 218-226.

Raval KN, Hellwig S, Prakash G, Ramos-Plasencia A, Srivastava AK, Biichs J. Necessity of a two-stage process for the production of azadirachtin-related limonoids in suspension cultures of Azadirachta indica. J Biosci Bioeng. 2003; 96(1): 16-22.

Rodrigues M, Paiva R, Nogueira RC, Martinotto C, Silva Júnior JM. In vitro morphogenesis of neem from cotyledonary-derived explants. Rev Árvore. 2009; 33(1): 21-26.

Rodrigues M, Costa THF, Festucci-Buselli RA, Silva LC, Otoni WC. Effects of flask sealing and growth regulators on in vitro propagation of neem (Azadirachta indica A. Juss.). In Vitro Cell Dev Biol Plant. 2012; 48(1): 67-72.

Sanchez-Sampedro MA, Fernández-Tárrago J, Corchete P. Elicitation of silymarin in cell cultures of Silybum marianum: effect of subculture and repeated addition of methyl jasmonate. Biotechnol Lett. 2009; 31(10): 1633-1637.

Satdive RK, Fulzele DP, Eapen S. Enhanced production of azadirachtin by hairy root cultures of Azadirachta indica A. Juss by elicitation and media optimization. J Biotechnol. 2007; 128(2): 281-289.

Savitha BC, Timmaraju R, Bhagya-Laksami N, Ravishankar GA. Different biotic and abiotic elicitors influence betalin production in hairy root cultures of Beta vulgaris in shake flask and bioreactor. Process Biochem. 2006; 41(1): 50-60.

Schaaf O, Jarvis AP, van der Esch SA, Giagnacovo G, Oldham NJ. Rapid and sensitive analysis of azadirachtin and related triterpenoids from neem (Azadirachta indica) by high performance liquid cromatography atmospheric pressure chemical ionization mass spectrometry. J Chromatogr A. 2000; 886(1-2): 89-97.

Sujanya S, Devi PB, Sai I. In vitro production of azadirachtin from cell suspension cultures of Azadirachta indica. J Bioscience. 2008; 33(1): 113120. 
Suriyan CU, Kirdmanee C. Proline accumulation, photosynthetic abilities and growth characters of sugarcane (Saccharum officinarum L.) plantlets in response to iso-osmotic salt and water-deficit stress. Agr Sci China. 2009; 8(1): 51-58.

Stamp N. Out of the quagmire of plant defense hypotheses. The Quart Rev Biol. 2003; 78(1): 23-55.

Thengane S, Joshi M, Mascarenhas AF. Somatic embryogenesis in neem (Azadirachta indica). In: Jain SM, Gupta P, Newton R (Eds.) Somatic Embryogenesis in Woody Plants. vol II, Important Selected Plants. Kluwer Academic Publishers, Dordrecht: 1995 . p. 357-374.
White PR. The cultivation of animal and plant cells, $2^{\text {nd }}$ ed. Ronald Press, New York: 1963. p. 109-112.

Zhao J, Davis LC, Verpoorte R. Elicitor signal transduction leading to production of plant secondary metabolites. Biotechnol Adv. 2005; 23(4): 283-333.

Received: November 13, 2012; Accepted: October16, 2013. 